\title{
РАЦІОНАЛЬНІ НАВЧАЛЬНІ ПЛАНИ ЯК ЗАПОРУКА ЯКІСНОЇ ПІДГОТОВКИ МАГІСТРІВ ЗА СПЕЦІАЛЬНІСТЮ “МЕДИЦИНА”
}

\author{
Ю. В. Думанський, П. Г. Кондратенко, М. В. Конькова, О. В. Кетінг \\ Донецький національний медичний університет імені М. Горького
}

\section{RATIONAL EDUCATIONAL PLANS AS A GUARANTEE OF QUALITY TRAINING MASTER'S DEGREE IN “MEDICINE”}

\author{
Yu. V. Dumanskyi, P. H. Kondratenko, M. V. Konkova, O. V. Kietinh \\ M. Gorky Donetsk National Medical University
}

\begin{abstract}
Основним пріоритетом розвитку сучасної медичної освіти є постійне вдосконалення навчально-методичних підходів до підготовки лікарів, внесення доповнень та змін до робочих навчальних планів і програм відповідно до потреб практичної охорони здоров'я. Скорочення кількості аудиторних годин відповідно до Закону України “Про вищу освіту” зумовлює необхідність відповідального ставлення до їх розподілу між навчальними дисциплінами. Вища медична освіта - досить специфічний та несхожий на інші освітній процес. Вже 31 курсу студенти-медики повинні отримувати великий обсяг базисних медичних знань та вмінь.

У роботі висвітлено основні проблеми розподілу аудиторних годин між курсами та навчальними дисциплінами: штучно збільшена або, навпаки, недостатня кількість виділених на предмет годин, дублювання однієї і тієї ж тематики на різних кафедрах при їі викладанні у складі різних дисциплін, відсутність послідовності подачі матеріалу, недостатня сучасність та розірваність отриманих студентами медичних знань. Вказане нераціональне використання аудиторних годин $\epsilon$ неприпустимим. Автори припускають, що частковий перерозподіл годин може виявитися дуже корисним.

Якісна підготовка лікарів значною мірою залежить від раціонального використання наявних аудиторних годин, що можливо тільки за умови перегляду робочих навчальних планів підготовки фахівців з урахуванням принципу послідовного, логічного та сучасного викладання дисциплін у медичному університеті.
\end{abstract}

The main priority of modern medical education is continuous improvement of teaching approaches to the training of doctors, making additions and changes to educational plans and programs meet the needs of health care. Reducing the number of classroom hours under the Law of Ukraine on higher education necessitates a responsible attitude to their distribution between academic disciplines. Higher medical education is rather specific and unlike other educational process. From the 1st year medical students should receive a large amount of basic medical knowledge and skills.

The paper highlights the main problems of distribution of classroom hours between courses and academic disciplines, artificially increased or, conversely, insufficient quantity of hours, duplication of the same subject in different departments during it teaching in the various disciplines, lack of modernity, as well as fragmentation, lack modern and dissociation students received medical knowledge. Said inefficient use of classroom hours is unacceptable. The authors suggest that partial redistribution hours can be very useful.

Quality medical education to a large extent depends on the the rational use of available classroom hours. This is possible only if to review educational plans according to the principle of sequential, logical and modern teaching subjects in medical university.

Вступ. Основним пріоритетом розвитку сучасної медичної освіти є постійне вдосконалення навчально-методичних підходів до підготовки лікарів, внесення доповнень та змін до робочих навчальних планів і програм відповідно до потреб практичної охорони здоров’ я. Аналіз робочих навчальних планів підготовки фахівців у галузі знань “Охорона здоров’я” за спеціальністю “Медицина” освітньо-кваліфікаційного рівня “Магістр” кваліфікації “Лікар” у Донецькому національному медичному університеті імені М. Горького показав, що підходи до використання аудиторних годин потребують перегляду та вдосконалення.

Основна частина. Скорочення кількості аудиторних годин відповідно до Закону України “Про вищу освіту” зумовлює необхідність відповідального ставлення до їх розподілу між навчальними дисциплінами. Варто пам’ятати, що вища медична освіта - досить специфічний та несхожий на інші освітній процес. Вже з 1 курсу студенти-медики повинні отримувати великий обсяг базисних медичних знань та вмінь. Тому кожна аудиторна година безцінна.

\footnotetext{
() Ю. В. Думанський, П. Г. Кондратенко, М. В. Конькова, О. В. Кєтінг
} 
Так, на вивчення історії України та історії української культури на 1 курсі медичного факультету передбачено по 20 аудиторних годин, що, 3 нашої точки зору, дублює знання, які були отримані студентами під час навчання у загальноосвітній школі. Водночас на такі необхідні студенту-медику дисципліни, як медична хімія, біоорганічна та біологічна хімія, передбачено лише 70 та 30 годин відповідно. Вивчення основ педагогіки студентами першого курсу є передчасним.

На нашу думку, потребує переносу з 2 на 1 рік навчання курс за вибором “Деонтологія в медицині”, але не в якості курсу за вибором, а обов’ язкової навчальної дисципліни. Таким чином, частковий перерозподіл годин може виявитися дуже корисним.

Засвоєння студентами знань з анатомії та гістології повинно проходити паралельно, то ж початок вивчення цих дисциплін має збігатися, що дозволить полегшити сприймання інформації студентами.

Перегляд аудиторних годин 2 року навчання свідчить про необхідність переносу топографічної анатомії до складу анатомії (без збільшення годин), а оперативної хірургії - до складу загальної хірургії (з трансфером відповідних годин), що зумовлено сучасним викладанням зазначених дисциплін та дозволить запобігти дублюванню інформації у педагогічному процесі.

Можливо, є обгрунтованим вивчення мікробіології на одному (наприклад, другому) курсі, а не розірвання дисципліни між 2 та 3 роками навчання.

Засвоєння медичної психології студентами 3 курсу є передчасним, більш логічним було би вивчення цієї дисципліни на 4 році навчання, $з$ прив'язкою до курсу психіатрії та отримання знань 3 деяких клінічних дисциплін.

3 метою уникнення розірваності медичних знань доцільно сконцентрувати дисципліни хірургічного профілю (онкологія, травматологія, нейрохірургія, урологія, отоларингологія) на одному курсі навчання. Це ж стосується й терапевтичних дисциплін (неврологія, психіатрія, наркологія, дерматологія, венерологія, фтизіатрія, інфекційні хвороби).

Потребує збільшення кількість годин, відведених на фізичну реабілітацію та спортивну медицину (40 годин), радіологію (80 годин на вивчення основ всіх сучасних методів візуалізації!), отоларингологію (40 годин), офтальмологію (40 годин), нейрохірургію (30 годин), анестезіологію та інтенсивну терапію (60 годин). Наявність 30-40 аудиторних годин на вивчення нейрохірургії, офтальмології та отоларингології навряд чи дозволить вважати ситуацію із засвоєнням великого спектра переліченої патології задовільною.

Останнім часом у зв'язку з військовими діями на сході України проблема медичної реабілітації $€$ вкрай гострою. 40 аудиторних годин, які відведено на фізичну реабілітацію і спортивну медицину на 4 році навчання, не забезпечать бажаного рівня знань та оволодіння вміннями. Чи не варто переглянути ці години з метою повноцінного засвоєння методів фізичної реабілітації студентамимедиками?

Фтизіатрія викладається студентам 4 (40 годин) та 6 (15 годин) курсів у складі внутрішньої медицини. Соціальна медицина та організація охорони здоров'я вивчається студентами 4, 5 та 6 курсів (40, 20 та 40 годин відповідно). Чи не доцільно засвоїти дисципліни на одному (можливо, випускному) курсі?

Дитячу хірургію у складі хірургії вивчають студенти як 5 (30 годин), так і 6 курсу (16 годин). Достатньо логічним виглядає об'єднання годин 3 дитячої хірургії на якомусь одному році навчання. Аналогічна ситуація склалась з дитячими інфекційними хворобами у складі педіатрії на 5 та 6 курсах (30 і 45 годин відповідно).

Дуже важливою є проблема викладання однієї і тієї ж тематики на різних кафедрах та у складі різних дисциплін. Так, променева хвороба викладається на радіаційній медицині, професійних хворобах, внутрішній медицині у складі військової терапії, медицині катастроф. Така ж ситуація склалась 3 отруєнням хімічними речовинами, серцеволегеневою реанімацією та іншими розділами. Вказане нераціональне використання аудиторних годин $\epsilon$ неприпустимим.

Безумовно, такий погляд на навчальні робочі плани призводить до поломки стереотипів, але $\epsilon$ викликом сьогодення. Зміщення акцентів у бік тих розділів медицини, які швидко розвиваються та перспективні, $є$ сучасною необхідністю.

Висновок. Якісна підготовка лікарів значною мірою залежить від раціонального використання наявних аудиторних годин, що можливо тільки за умови перегляду робочих навчальних планів підготовки фахівців з урахуванням принципу послідовного, логічного та сучасного викладання дисциплін у медичному університеті. 


\section{Список літератури}

1. Закон України “Про вищу освіту” (Відомості Верховної Ради, 2014, № 37-38, ст. 2004) із змінами, внесеними згідно із Законом від 28.12.2014 р. № 76-VIII // BBP. - 2015. - № 6 .
2. Інновації у вищій освіті: проблеми, досвід, перспективи : монографія / за ред. П. Ю. Сауха. - Житомир : Вид-во ЖДУ ім. М. Франка, 2011. - 444 с.

Отримано 04.04.16 